\title{
Microscopic Features of Gonadally Inactive Testis of Khaki Campbell Duck (Anas platyrhynchos domesticus) in Bangladesh
}

\author{
Papia Khatun ${ }^{1, a, *}$, Ziaul Haque ${ }^{2, b}$, Shonkor Kumar Das ${ }^{2, c}$ \\ ${ }^{1}$ Department of Anatomy \& Histology Faculty of Veterinary, Animal and Biomedical Sciences Khulna Agricultural University Khulna-9100, \\ Bangladesh \\ ${ }^{2}$ Department of Anatomy \& Histology Faculty of Veterinary Science Bangladesh Agricultural University Mymensingh-2202, Bangladesh \\ *Corresponding author
}

\section{A R T I C L I N F O A B S T R A C T}

Research Article

The microscopic features of the testis were studied in gonadally inactive Khaki Campbell duck (Anas platyrhynchos domesticus) in Bangladesh. The study was conducted in the Department of Anatomy \& Histology, Bangladesh Agricultural University, Mymensingh. Five adult healthy birds of one-year-old were used for this study. The testes were collected immediately after ethical killing

Received : 29/07/2020

Accepted : 18/09/2020 of the birds for histological observations. The collected tissue samples were then processed and stained with Hematoxylene \& Eosin (H \& E) stain for histological observations. The seminiferous tubules showed considerable involution with cessation of spermatogenesis. The basal lamina of the seminiferous tubules was irregular in outline and was invaginated into the germinal epithelium in the form of finger-like plicae or folds. Most of the lumen of the seminiferous tubules was empty and all generation of germ cells were not present in most of the seminifeous tubules. The interstitium

Keywords:

Microscopic

Inactive testis

Khaki Campbell duck

Reproductive cycle

Seminiferous tubule showed a relative increase in volume and interstitial tissue consisted of loose connective tissue, interstitial cells (Leydig cells), few connective cells and blood vessels. This study first time described the microscopic features of testis of Khaki Campbell ducks in Bangladesh during inactive phases of the reproductive cycle.

papiakhatundvm@gmail.com (iD) https://orcid.org/0000-0002-3453-4145 skdas76@yahoo.com

\section{Introduction}

Cyclical patterns of testicular activity and inactivity has been observed in the most of the avian species with a period of rapid testicular re-growth in mature males just prior to the start of the breeding season (Murton and Westwood, 1977). After breeding, the testes regress and remain inactive until the next breeding season. The size and histological feature of the avian testis varies greatly between the non-breeding and breeding seasons. Vertebrate's reproduction is under endogenous regulation and generally depends also on environmental factors. In birds, the constant seasonal reproductive cycles are influenced by environmental factors such as light, temperature, rainfall index and food availability (Kemp, 1973; Silverin, 1975). The internal morphological changes of the testis reflect the changes in the breeding activity of birds. Although details investigations on the histology of testes have been performed in some domestic poultry such as roosters (Rothwell, 1975; Trefil et al., 2006; Aire and Ozegbe, 2007; Bull et al., 2007), Muscovy ducks (Marchand and Gomot, 1973; Gerzilov et al., 2002; Islam et al., 2013), geese (Mori and George, 1978; Halse, 1985), turkeys (Noirault et al., 2006; Aire and Ozegbe, 2007; Bakst et al., 2007), ducks (Aire and Ozegbe, 2007; Elbajory et al., 2013), Japanese quails (Lin et al., 1990; Maretta and Marettova, 2004; Al-Tememy, 2010) guinea fowl (Dharani et al., 2017), but investigations on the gonadally inactive testis of Khaki Campbell duck in Bangladesh has not performed yet. On the other hand, the economy of Bangladesh largely depends on agriculture and poultry, is a raising sector now. Among poultry, ducks are considered as a second widespread species following the chickens in Bangladesh (Ahmed, 1986). Nowadays, Khaki Campbell (Anas paltyrhynchos domesticus) duck is becoming more popular but this species is really less focused. The duck production in Bangladesh turns to be a big industry for supplying the animal protein to the mass people in near future. So, it is high time to in depth knowledge about Khaki Campbell duck. Focusing on reproduction, the present research is worthy in this realm. The structural changes of the testicular cells occur according to age and reproductive cycle (Gerzilov et al., 2002). On the other hand, basic research is decreasing day 
by day although we know basic research is the foundation of other applied and clinical research.

Therefore, the present study is aimed to: investigate the microscopic features of gonadally inactive testes of Khaki Campbell duck in Bangladesh and to: compare the histological features of gonadally inactive testes of Khaki Campbell duck with other avian species.

\section{Materials and Methods}

The research was conducted in the post-graduate laboratory of Department of Anatomy and Histology, Faculty of Veterinary Science, Bangladesh Agricultural University (BAU), Mymensingh-2202, Bangladesh. Guidelines for the care and use of animals as established by Animal Welfare and Experimentation Ethics Committee, Bangladesh Agricultural University, Mymensingh, Bangladesh [AWEEC/BAU/2019(30)] were followed during conducting this study.

Five apparently healthy male Khaki Campbell ducks (Anas platyrhynchos domesticus) of one-year-old were used in the present study. The ducks were collected from poultry farm of BAU, Mymensingh. After taking live body weight, birds were sacrificed by cervical sub-luxation method. After dissection of carcasses, testes were removed and tissue pieces were collected from different regions of the testis and subsequently fixed in $10 \%$ formalin solution. All the tissues were processed for paraffin sections by alcohol-xylene method. Sections were cut at 5-6 $\mu \mathrm{m}$ thickness using a Rotary Microtome (American Optical Spencer Model 820) and stained with (H\&E) stain.

Necessary photographs were taken during histological examination for better illustration of the result. The histological pictures were taken with photographic light microscope (Axiocam ERc 5s) and placed for better illustration of the result. The histological parameters were measured by using pre-calibrated ocular micrometer.

\section{Results}

Each testis was covered by testicular capsule which was not uniform in structure and sloughed off in some places

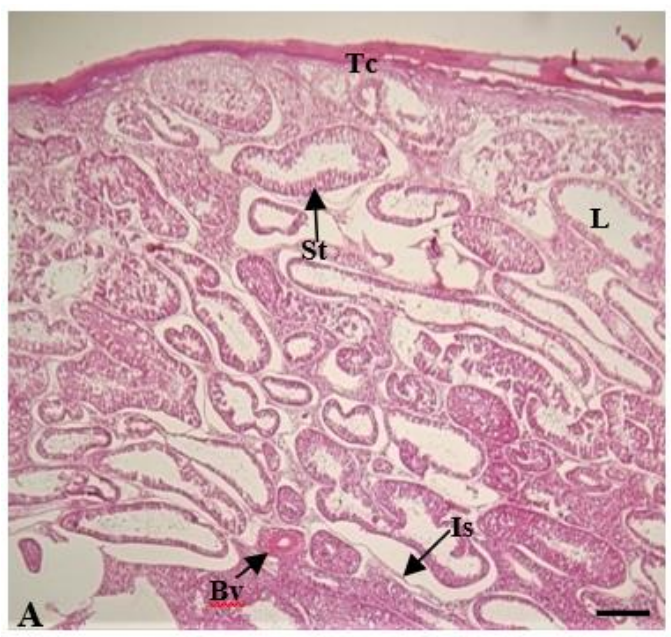

(Figure 1A). The testicular capsule was comprised of dense connective tissue with presence of fibroblasts. The thickness of the testicular capsule was $72.12 \pm 2.94 \mu \mathrm{m}$. In examined observation fields, there were no thick connective tissue stripes dividing the testicular parenchyma into lobes and lobules (Figure 1A). In this study, clear regression signs of testicular parenchyma were demonstrated. Seminiferous tubules were atrophic and most of the tubules were collapsed. The seminiferous tubules were irregular in shape and size. They were not closely attached with one another (Figure 1A). The diameter of the seminiferous tubules was also reduced. The mean length and width of the seminiferous tubules was $468.6 \pm 166.91 \mu \mathrm{m}$ and $231.46 \pm 41.68 \mu \mathrm{m}$ respectively. The basal lamina of the seminiferous tubule is irregular in outline and commonly thick. In some seminiferous tubules, the basal lamina was invaginated into the germinal epithelium in the form of finger-like plicae or folds (Figure 1B). Anastomoses among the different seminiferous tubules were also noticed. The tubules lumen was relatively large, irregular and most of the lumen was empty (Figure 1B), few were filled with spermatozoa. There was also increased cellular debris in the tubular lumen (Figure 1B). One major change was the presence of sloughed-off cells in the seminiferous tubular lumen (Figure 1B). As a result, most cells were not located within appropriate cellular associations. Generally, fewer germ cells were found in the most of the seminiferous tubules (Figure 2A and $2 \mathrm{~B}$ ), and germ cells beyond the primary spermatocyte stage were mostly affected. There were a few seminiferous tubules in which all generation of germ cells such as spermatogonia, primary and secondary spermatocyte, spermatid and spermatozoa were found (Figure 3A). The sertoli cells were round to slender with irregular outline (Figure 3A). They extended from the basement membrane to the lumen of the seminiferous tubules.

Increased interstitial space was observed in this study. The interstitial cells were numerous. Leydig cells were scattered in the interstitial spaces. They were polygonal in shape with a large spherical nucleus (Figure 3B). Blood vessels were also present in the interstitial space (Figure $1 \mathrm{~A})$.

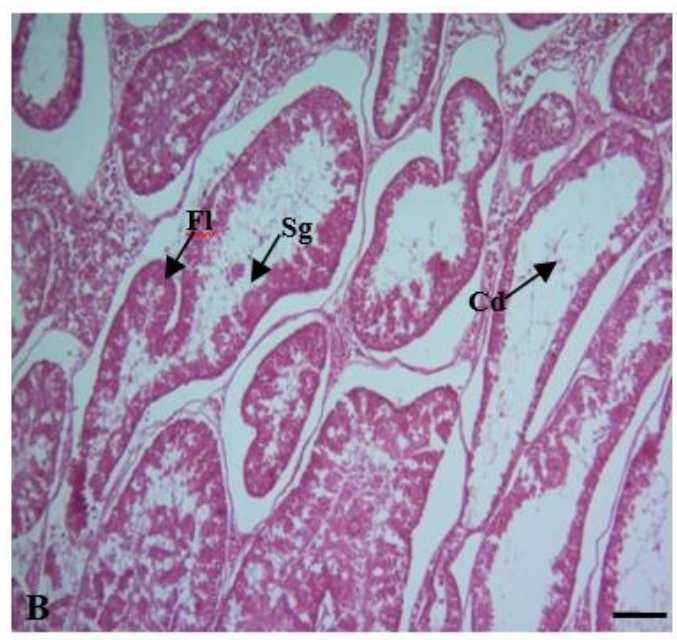

Figure 1. Photomicrographs of the inactive testis of Khaki Campbell duck showing testicular capsule (Tc), irregular

shaped seminiferous tubule ( $\mathrm{St}$ ), fingure like folding of seminiferous tubule (Fl), irregular and empty lumen (L), sloughed off cells (Sg), cellular debris (Cd) within the lumen of some seminiferous tubules, increased interstitial space (Is), blood vessel (Bv) in interstitial space. Scale bar: $100 \mu \mathrm{m}(\mathrm{A}), 50 \mu \mathrm{m}(\mathrm{B})$. 


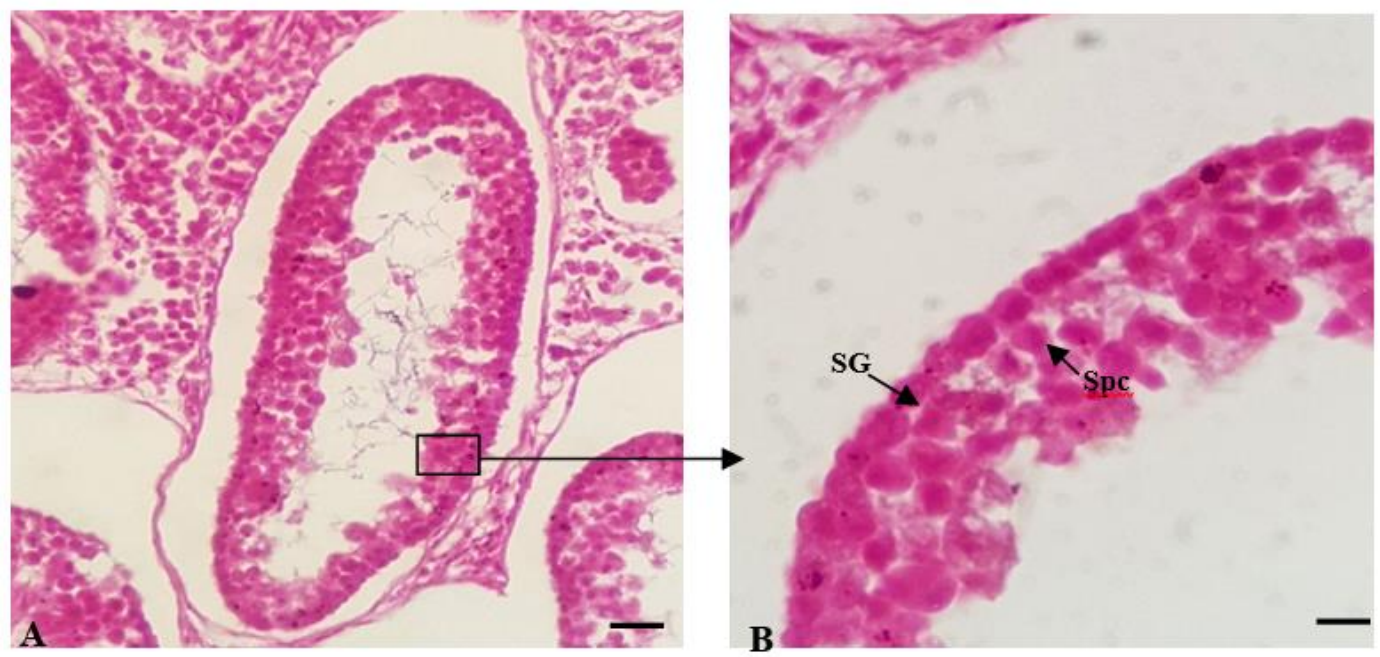

Figure 2. Photomicrographs of the inactive testis of Khaki Campbell duck showing regressed seminiferous tubule with few germ cells generation (A), Spermatogonia (SG), Spermatocyte (Spc). Scale bar: $10 \mu \mathrm{m}(\mathrm{A}), 5 \mu \mathrm{m}$ (B).
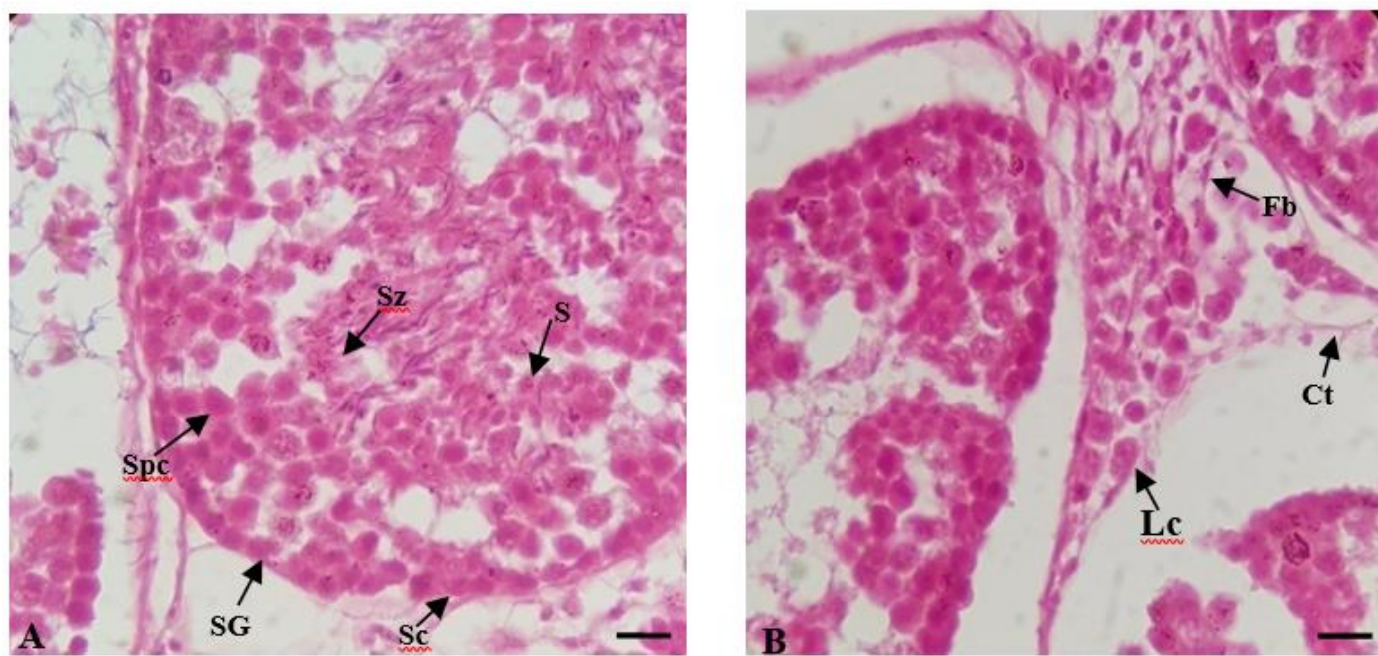

Figure 3. Photomicrographs of the inactive testes of Khaki Campbell duck showing seminiferous tubule with spermatogonia (SG), spermatocyte (Spc), round spermatid (S), spermatozoa (Sz), sertoli cell ( $\mathrm{Sc}$ ), interstitial space contained connective tissue fibes $(\mathrm{Ct})$, fibroblasts $(\mathrm{Fb})$, leydig cell (Lc). Scale bar: $5 \mu \mathrm{m}(\mathrm{A} \& \mathrm{~B})$.

\section{Discussion}

The microscopic features of the testicular capsule in Khaki Campbell ducks were nearly similar to that of other birds reported by Aire (1997); Jamieson (2007), in Sudanese duck by Aire and Ozegbe, (2007) and Salwa et al. (2013), in white rooster by Razi et al. (2010), in Muscovy duck by Gerzilov et al. (2016) with the exception of sloughing of testicular capsule in some places found in present study. This variation may be due to species differences and state of reproductive inactivity of testis. No lobulation of testicular parenchyma was observed in present study which was similar to those found in white rooster by Razi et al. (2010), Muscovy duck by Gerzilov et al. (2016), Sudanese duck by Salwa et al. (2013), indigenous duck by Khadem (2014). The thickness of testicular capsule that was found in this study was lower than that has been reported by Aire and Ozegbe (2007) in birds, by Hodges (1974) in domestic fowl that was measured in gonadally active birds. The specific reason for this difference in testicular capsule thickness is not clearly known, but could be due to age of the subjects, species difference and possibly but not probably reproductive activity.
The irregular shape of the seminiferous tubules, decreased diameter of the seminiferous tubules, fingure like folding of basal lamina, presence of cellular debris in the tubular lumen, degenerating germ cells and collapse of seminiferous tubules observed in the present study also reported by Victor and Wilbor (1974) in Japanese quail (Coturnix coturnix japonica), by Gumulka and Rozenboim (2015) in gander (Anser anser domesticus), by AbdulRahman et al. (2015) in guinea fowl, by Simoes et al. (2017) in domestic duck. Whereas complete seminiferous tubular structure with presence of all generation of germ cells was observed in gonadally active bird reported by Razi et al. (2010) in white rooster, by Salwa et al. (2013) in Sudanese duck, by Gerzilov et al. (2016) in Muscovy duck.

In present study, it was observed that the interstitial space was increased. Numerous interstitial cells with scattered polygonal shaped leydig cells were found in the interstitial spaces. Blood vessels were also present in interstitial space. Similar findings were reported by Aire (1997) in domestic fowl, duck, quail and guinea fowl, Dharani et al. (2017) in guinea fowl. 


\section{Conclusion}

From the above study, it can be concluded that the histological feature of the testis of the Khaki Campbell duck varies greatly between the active and inactive period of the reproductive cycle. These basic histological features will provide valuable information for morphometric analysis of testicular cells and quantitative assessment of the inactive testis of Khaki Campbell duck to the anatomist, poultry or duck researchers, poultry farmers, veterinarians and autonomous learners.

\section{Acknowledgements}

The authors acknowledged the Department of Anatomy and Histology, Bangladesh Agricultural University, Mymensingh-2202 for completion of the research work.

\section{Conflict of Interest}

The authors declare that they have no conflict of interest.

\section{References}

Abdul-Rahman, Robinson JE, Obese FY, Jeffcoate IA, Awumbila, B. 2015. Effects of season on the reproductive organ and plasma testosterone concentrations in guinea cocks (Numida meleagris). Poultry Science, 95(3): 636-644.

Ahmed S. 1986. Duck production in Bangladesh. In "Duck Production Science and World Practice". Farrell, D.J. and Stapleton, P. (Ed). University of New England, Armidale, Australia, pp. 342-350.

Aire TA. 1997. The structure of the interstitial tissue of the active and resting avian testis. Onderstepoort Journal of Veterinary Research, 64: 291-299.

Aire TA, Ozegbe PC. 2007. The testicular capsule and peritubular tissue of birds: morphometry, histology, ultrastructure and immunohistochemistry. Journal of Anatomy, 210: 731-740.

Al-Tememy, H. 2010. Histological study of testis in quail (Coturnix coturnix japonica). Journal of Veterinary Sciences, 3: 36-44.

Bakst MR, Akuffo VP, Brillard JP. 2007. Morphological and histochemical characterization of the seminiferous epithelial and leydig cells of the turkey. Animal Reproduction Science, 97: 303-313.

Bull ML, Martins MRFB, Cesario MD, Padovani CR, Mendes AA. 2007. Anatomical study on domestical fowl (Gallus domesticus) reproductive system. International Journal of Morphology, 25(4): 709-716.

Dharani P, Kumary SU, Sundaram V, Joseph C, Ramesh G. 2017. Morphology of the interstitial tissue of active and resting testis of the Guinea fowl. International Journal of Morphology, 35(4): 1359-1362.

Elbajory SIA, Tingari MD, Abdalla MA. 2013. Morphological study of the testis of adult Sudanese duck (Anas platyrhynchos). International Journal of Animal and Veterinary Advances, 5: 103-107.

Gerzilov V, Vitanov SM, Nikolov I. 2002. Morphological and histological assessment of testes of Muscovy drakes producing ejaculates two-and threefold weekly. Animal Science, 39: 119-123.

Gerzilov V, Bochukov A, Penchev G, Petrov P. 2016. Testicular Development in the Muscovy duck (Cairina moschata). Bulgarian Journal of Veterinary Medicine, 19(1): 8-18.

Gumulka M, Rozenboim I. 2015. Effect of breeding stage and photoperiod on gonadal and serotonergic axes in domestic ganders. Theriogenology, 84(8): 1332-1341.
Halse A. 1985. Gonadal cycles and levels of luteinizing hormone in wild spur-winged geese (Plectropterus gambensis). Journal of Zoology, 205: 335-355.

Hodges RD. 1974. The reproductive system. In The Histology of the Fowl. Academic Press, London. pp. 300-326.

Islam FS, Ishishita Y, Uno B, Mollah K, Matsuda SY. 2013. Male hybrid sterility in the mule duck is associated with meiotic arrest in primary spermatocytes. Journal of Poultry Science, 50: $311-320$.

Jamieson Barrie GM. 2007. Reproduction Biology and Phylogeny of Birds, part A. University of Queensland, Australia, pp. 44-46.

Kadhem AZ. 2014. The cycle event of spermatogenesis and spermiogenesis in the testes of indigenous duck (Anas platyrhynchos). Bashra jornal of veterinary Research, 13(2): 16-22.

Kemp AC. 1973. Environmental factors affecting the onset breeding in some Southern African hornbills, Tockus spp. Journal of Reproduction and Fertility, 19: 319-331.

Lin M, Jones RC, Blackshaw AW. 1990. The cycle of the seminiferous epithelium in the Japanese quail (Coturnix coturnix japonica) and estimation of its duration. Journal of Reproduction and Fertility, 88: 481-490.

Marchand CR, Gomot L. 1973. Etude histologique et cytologique des testicules et des voies genitals du canard de Barbarie (Cairina moshata L.). en activite sexuelle. Journées de Recherches Avicoles et Cunicoles, 5: 127-134.

Maretta M, Marretova E. 2004. Immunohistochemical demonstration of myoid cells in the testis and its excurrent ducts in the domestic fowls. British Poultry Science, 45: 585589.

Mori G, George C. 1978. Seasonal histological changes in the gonads, thyroid and adrenal of the Canada goose (Branta Canadensis interior). Journal of Acta Anatomica, 101: 304324.

Murton RK, Westwood NJ. 1977. Avian Breeding Cycles. Oxford University Press, Oxford.

Noirault J, Brillard JP, Bakst MR. 2006. Spermatogenesis in the turkey (Meleagridis gallopavo): Quantitative approach in immature and adult males subjected to various photoperiods. Theriogenology, 65: 845-859.

Razi M, Hassanzadeh SH, Najafi GR, Feyzi S, Amin M, Moshtagion M, Janbaz H, Amin M. 2010. Histological and anatomical study of the White Rooster of testis, epididymis and ductus deferens. International Journal of Veterinary Research, 4(4): 229-236.

Rothwell B. 1975. Designation of the cellular component of the peritubular boundary tissue of the seminiferous tubule in the testis of the fowl (Gallus domesticus). British Poultry Science, 16: 527-529.

Salwa I, Abdelgader E, Tingari DE, Mohamed A. 2013. Morphological Study of the Testis of Adult Sudanese Duck (Anas platyrhynchos). International Journal of Animal and Veterinary Advances, 5(3): 103-107.

Simoes K, Orsi AM, Schimming BC, Benetti EJ. 2017. Seasonal reproductive cycle and variability in plasma testosterone levels in the domestic duck (anas platyrhynchos). Bioscience journal, 33(1): 153-164.

Silverin B. 1975. Reproductive organs and breeding behavior of the male pied Flycatcher Ficedula hypoleuca (Pallas). Scandinavian Journal of Ornithology, 6(1): 15-26.

Trefil P, Micakova A, Mucksova J, Hejnar J, Poplstein M, Bakst M, Kalina J Brillard, JP. 2006. Restoration of spermatogenesis and male fertility by transplantation of dispersed testicular cells in the chicken. Biology of Reproduction, 75: 575-581.

Victor PE, Wilbor OW. 1974. Histological changes in the regressing reproductive organs of sexually mature male and female Japanese quail. Biology of Reproduction, 11: 168-179. 